Article

\title{
Composite Performance Evaluation of Basalt Textile-Reinforced Geopolymer Mortar
}

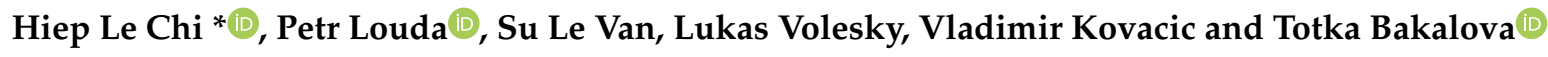 \\ Department of Material Science, Faculty of Mechanical Engineering, Technical University of Liberec, \\ Studenstká 2, 46117 Liberec, Czech Republic \\ * Correspondence: lechihieptu109@gmail.com
}

Received: 17 June 2019; Accepted: 4 July 2019; Published: 11 July 2019

\begin{abstract}
Basalt fiber is a novel type of inorganic fiber which is produced from the extrusion of natural vocalnic basalt rocks through their melting process at high temperature. So the quality and strength characteristics of basalt fiber depend mainly on both the quality of raw material and manufacturing processing. Basalt fabric-reinforced cementitious composites (FRCM) are a novel composite and an extensive scientific investigation is still ongoing for geopolymer composite. Based on three types of basalt textile with respect to various net sizes, the aim of this paper is to evaluate the flexural performance of basalt textile-reinforced geopolymer composite through the four-point bending test. The specimens of rectangular form with the dimension of $400 \times 100 \times 15 \mathrm{~mm}^{3}$, reinforced with one to four layers of each type of basalt textile, were produced. They were then tested at the age of about 40 days after casting. On the other hand, the number of the specimens reinforced with four layers were considered to assess the mechanical strength of the specimens at longer periods of ageing time $(60,90,150,180$ days). The experimental results showed that with the increasing number of reinforcing layers, the specimens significantly improved the mechanical strength, except for those reinforced with basalt textile of big net size. The specimens reinforced with basalt textile of big net size had no impact on post-crack mechanical strength, however, it helps to arrest the catastrophic brittle failure of the specimens; the failure of these specimens is due to localization of first crack. When the specimens were exposed to the further ageing times, the mechanical strength of the specimens were decreased over time. All the reinforced specimens have the same failure mode by flexural failure due to the rupture of fiber yarn in matrix, and no debonding of fiber yarn or a gradual peeling process of mortar matrix happened during testing.
\end{abstract}

Keywords: geopolymer; basalt textile; chopped basalt fiber; four-point bending test; compressive strength; flexural strength; flexural toughness

\section{Introduction}

Textile-reinforced concrete (TRC) is a composite material resulting from a combination of multi-axial textile reinforcement and fine-grained aggregate-based cementitious matrix. The textile reinforcements used as reinforced in concrete are alkali resistance glass, carbon, basalt or aramid fabrics. The textile reinforcement plays a key role in carrying the bearing capacity and stiffness of composite materials. It is well-known for some significant advantages: (i) due to the possibility of the intentional alignment of textile fabric in concrete, it can be placed at the position where the stress is required, as a result of improved tensile strength and ductility, (ii) composite materials reinforced with these reinforcements are no need a strong concrete covering layer to protest against the corrosion of the structure, due to good alkali resistance of reinforcement, (iii) compared to fiber reinforced polymer composite, TRC exhibits lower cost, better temperature resistance, greater compatibility with most substrates. This type of composite can be used in a variety of the applications, such as repairing and/or 
strengthening the structural elements of old structures, load-bearing elements in new structures, new thin-wall elements and the lightweight concrete system [1-4].

Geopolymers are inorganic aluminosilicate polymers with non-crystalline networks, which are ceramic-like in their structures and properties [5]. Geopolymers are synthesized from a combination of an alkaline solution and the amorphous or semi-crystalline aluminosilicate materials at room, or slightly higher, temperature [6]. The final product is characterized by a stable amorphous 3D structure with a basic framework of tetrahedral $\mathrm{SiO}_{4}$ and $\mathrm{AlO}_{4}$ units linked alternatively by sharing oxygen atoms, where the metal cations $\mathrm{Na}^{+}, \mathrm{K}^{+}$are responsible for balancing the negative charges of $\mathrm{Al}^{3+}$ in IV-fold coordination [7-9]. In recent years, the geopolymer concept has become an attractive topic in research for the reason that geopolymer concrete offers great potential for alternative to Portland cement-based concrete. It is well-known that Portland cement is a construction building material with admirable mechanical properties which are proven. However, the Portland cement production process requires high energy consumption and it involves a large amount of $\mathrm{CO}_{2}$ emission. This binder is attributed to one of the major causes behind the global warming $[10,11]$. The appearance of geopolymer binder not only satisfies the mechanical properties but also pays attention to a novel green building material over Portland cement in the case that there is a reasonable choice of raw materials for geopolymers $[12,13]$. The eco-compatibility of geopolymers, and other peculiarities, such as acid resistance, seawater resistance, low shrinkage, thermal conductivity and fire resistance up to 1200 ${ }^{\circ} \mathrm{C}$ are not their general properties, but strongly depends on both the raw materials and amount and concentration and type of alkaline activator solution used. It is well known that when exclusively aluminosilicate sources, such as metakaolin, are used as reactive powder can be activated with a high amount of sodium silicate activators, thus, increasing geopolymer cost, carbon footprint and shrinkage. Furthermore, handling highly corrosive liquid is not a desirable condition. To overcome this problem, several attempts have been made by proposing new mix designs in which part or most of the metakaolin has been replaced by industrial by-product (such as activated slag and fly ash) or natural raw materials (volcanic tuff) that are more eco-friendly and need less alkaline activators $[14,15]$.

Basalt fibers are an environmentally friendly material made from natural volcanic basalt rocks through their melting process at high temperature of about $1500{ }^{\circ} \mathrm{C}$. The quality and strength characteristic of basalt fiber depends mainly on type of raw material and the manufacturing conditions [16]. Chemical compositions of basal fiber are rich in oxides of alumina and silica along a small amount of magnesium, calcium, sodium, potassium, silicon and iron [17]. It is observed that basalt is an inorganic fiber that is like glass fiber, has better tensile strength than the glass fiber, broader failure strain than the carbon fiber. Basalt fiber is a novel type of inorganic fiber that is considered as effective alternative material for glass fiber. Both of these products have similar manufacturing process, but basalt fiber obtains more economical and improved mechanical properties. Short basalt fiber added into concrete to fill some of the missing properties; such as, plastic shrinkage at early-age [18,19], splitting tensile and flexural strength, fracture energy, abrasion resistance, and impact resistance [20-24], whereas basalt fabric is used as flexural reinforcement for reinforcing concrete beams or reinforcing masonry panels [25-29].

In the field of geopolymer basalt fiber composites, many researches have been performed on short basalt fibers [18,30-34], continuous basalt fibers, or basalt fabrics as an reinforcement for geopolymer composite to improve their mechanical properties [35-39], however, according to the author's knowledge, little or no reports have been determined to date on the evaluation of performance of basalt fabric mesh reinforced geopolymer composites. Alkaline resistance of basalt fiber under accelerated aging or short-term aging conditions was investigated by some authors in previous studies [27,40-42]. It was concluded that when basalt fiber is treated in the alkaline environment, although it is proved to have partial loss of strength, it is less likely to be damaged than glass fiber. However, reports that evaluate the alkaline resistance of basalt fiber under realistic alkali environments (fiber embedded directly in the cement composite for long-term aging) are scarce. In another context, a lot of researches have been carried out on using fiber reinforced geopolymer composites for external 
strengthening layer of reinforced concrete members [43-48]. The results obtained from these researches stated that geopolymer composites can successfully be used as a matrix in fiber reinforced composite for strengthening systems.

This paper deals with the effect of three various types of basalt textile on the flexural performance of reinforced specimens, and also evaluation the development of flexural strength of the specimens at the further ages (60 days, 90 days, 150 days and 180 days). Geopolymer binder used in this study was activated with sodium based alkaline activator, which clearly states that basalt fiber will be partially damaged, as mentioned above. The aim of this paper is the assessment of whether these types of basalt mesh can satisfy as a flexural reinforcement in geopolymer composite.

\section{Materials and Methods}

\subsection{Materials}

Anticorrosive powder additive (microsilica) based on amorphous $\mathrm{SiO}_{2}$ for concrete and mortar was purchased from Kema Mikrosilika-Sanační centrum s.r.o., Sviadnov Czech Republic. The chemical composition of microsilica as follow (wt. \%): $\mathrm{SiO}_{2}-90, \mathrm{CaO}-0.8, \mathrm{MgO}-\max .1 .5, \mathrm{Al}_{2} \mathrm{O}_{3}-$ max. $1, \mathrm{Na}_{2} \mathrm{O}-0.5$. This additive was added into geopolymer mortar to enhance both the workability of the fresh mortar and mechanical strength of harden mortar. The three types of the basalt textile corresponding to the net size $\left(10 \times 14 \mathrm{~mm}^{2}\right.$ small net size, $22 \times 22 \mathrm{~mm}^{2}$ middle net size, $36 \times 36 \mathrm{~mm}^{2}$ big net size) provided by Frisiverto S.R.O company, Czech Republic are shown in Figure 1. The yarns of basalt textile (2400 Tex) were arranged in two orthogonal directions $\left(0 / 90^{\circ}\right)$ to form a textile grid, and they were coated using a styrene-butadiene binder. Further detailed properties are shown in Table 1. The composition of geopolymer mortar matrix was shown in Table 2. It must be noted that mixing ratio between the components in the geopolymeric mortar indicated in Table 2 was optimized in our lab room. In the four-point bending test of geopolymer composite specimens, basalt textiles were placed in the molds such that the force acting on the specimen was in the longitudinal direction of the yarn. The remaining materials (geopolymer binder, silica sand, chopped basalt fiber) used in this work and methodology of geopolymer mortar production were mentioned in the previous publication [30].

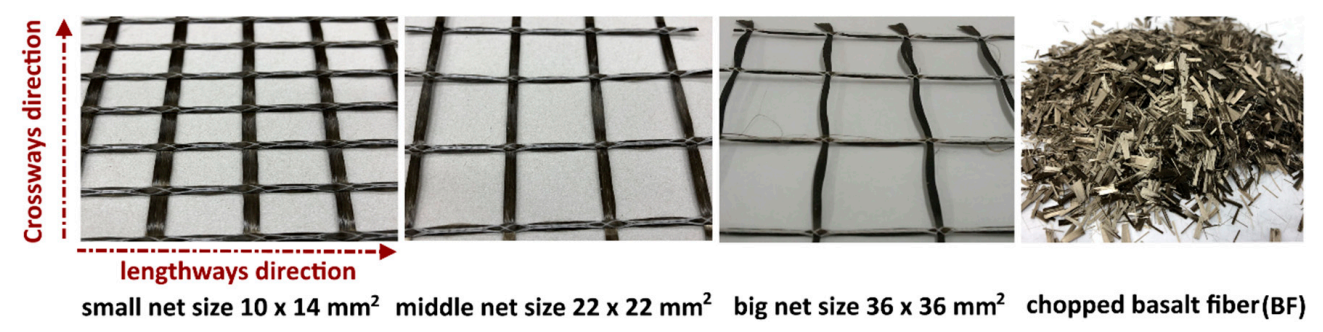

Figure 1. Image of basalt fiber meshes and chopped basalt fiber.

Table 1. Properties of the three various types of basalt textile provided by manufacturer.

\begin{tabular}{llll}
\hline \multicolumn{1}{c}{ Form } & \multicolumn{1}{c}{ Basalt Fiber Grid } & \multicolumn{1}{c}{ Basalt Fiber Grid } & \multicolumn{1}{c}{ Basalt Fiber Grid } \\
\hline Fiber type & Basalt HTB 10/14-40 & Basalt HTB 22/22-40 & Basalt HTB 36/36-40 \\
\hline Fiber density & $2.75 \mathrm{~g} / \mathrm{cm}^{3}$ & $2.75 \mathrm{~g} / \mathrm{cm}^{3}$ & $2.75 \mathrm{~g} / \mathrm{cm}^{3}$ \\
\hline \multirow{2}{*}{ Number of threads $/ \mathrm{m}$} & $\begin{array}{l}84 \text { (lengthways); } \\
61 \text { (crossways) }\end{array}$ & $\begin{array}{l}43 \text { (lengthways); } \\
42 \text { (crossways) }\end{array}$ & $\begin{array}{l}26 \text { (lengthways); } \\
25 \text { (crossways) }\end{array}$ \\
\hline \multirow{2}{*}{ weight } & $375 \mathrm{~g} / \mathrm{m}^{2}$ & $229 \mathrm{~g} / \mathrm{m}^{2}$ & $153 \mathrm{~g} / \mathrm{m}^{2}$ \\
\hline \multirow{2}{*}{ Stitch spacing } & $10 \times 14 \mathrm{~mm}$ & $22 \times 22 \mathrm{~mm}$ & $36 \times 36 \mathrm{~mm}$ \\
& $($ center to center distance) & $\begin{array}{l}\text { (center to center distance) } \\
\text { (center to center distance) }\end{array}$ \\
\hline \multirow{2}{*}{ Tensile strength } & $1335 \mathrm{~N} / \mathrm{mm}^{2}$ (lengthways); & $1068 \mathrm{~N} / \mathrm{mm}^{2}$ (lengthways) $;$ & $1141 \mathrm{~N} / \mathrm{mm}^{2}$ (lengthways); \\
& $1251 \mathrm{~N} / \mathrm{mm}^{2}$ (crossways) & $1347 \mathrm{~N} / \mathrm{mm}^{2}$ (crossways) & $1279 \mathrm{~N} / \mathrm{mm}^{2}$ (crossways) \\
\hline Elongation lengthways & $1.86 \%$ & $1.61 \%$ & $1.62 \%$ \\
\hline Elongation crossways & $1.50 \%$ & $1.63 \%$ & $1.54 \%$ \\
\hline
\end{tabular}


Table 2. Composition of geopolymer mortar matrix.

\begin{tabular}{|c|c|c|c|c|c|}
\hline \multicolumn{5}{|c|}{ By Weigh Ratio (-) } & \multirow{2}{*}{$\begin{array}{l}\text { BF Content (wt \% of } \\
\text { Geopolymer Paste) }\end{array}$} \\
\hline Geopolymer Cement & Activator & Micro Silica & Micro Sand & Rough Sand & \\
\hline 1 & 0.8 & 0.1 & 0.2 & 1.5 & 5 \\
\hline
\end{tabular}

\subsection{Specimen Preparation}

For the four-point bending test, the samples are molded in the rectangular form with the dimensions of $400 \times 100 \times 15 \mathrm{~mm}^{3}$. Basalt textile was used as reinforced with geopolymer mortar matrix, and the specimens were manufactured by hand lay-up method. The arrangement of basalt textile in the mold was clearly described in Figure 2. They were positioned in the mold with the desired distance by using the thin metal plates at the ends of the mold. It should be said that four reinforcing layers were eligible number in order to ensure easy penetration of geopolymer mortar between textile layers when the total thickness of the specimens was $15 \mathrm{~mm}$. For instance, the distance between two adjacent layers should be bigger than the size of sand grains, so this distance was $2 \mathrm{~mm}$ in the case of four reinforcing layers because the distance from center to center between two adjacent layers was $3 \mathrm{~mm}$ while self-thickness of fiber yarn was $1 \mathrm{~mm}$. The molds were manually vibrated for a while in order to ensure good penetration of fresh mortar between textile layers after being filled with mortar and textile. Figure 3 shows the manufacturing process of the reinforced specimens. It should be said clearly that the number of fiber yarns per one textile layer in the bearing direction is: eight yarns for small net size, four yarns for middle net size and three yarns for big net size. The label of reinforced specimens was defined as following: BRG means basalt textile reinforced geopolymer mortar, $00 \times 00 \mathrm{~mm}$ means a net size of basalt grid, and $0 \mathrm{~L}$ means the number of the textile layers. For example, label BRG $10 \times 14-1 \mathrm{~L}$ means that geopolymer mortar reinforced with one layer of the basalt grid having a net size of $10 \times 14 \mathrm{~mm}^{2}$. After casting, all the specimens were wrapped using a polypropylene film, and cured at room temperature, $\sim 26^{\circ} \mathrm{C}$, with $65 \%$ relative humidity for $24 \mathrm{~h}$. Afterwards, the specimens were demolded, and wrapped again using a polypropylene film, and kept at room temperature until testing. Three specimens for each mixture were prepared. They were tested at approximately 40 days after the casting.

\subsection{Four-Point Bending Test}

Four-point bending testthod was used to evaluate the composite performance of the BRG specimens. The detailed description about the specimen arrangement and testing process was shown in Figure 4. The testing machine with load cell capacity of $100 \mathrm{kN}$ (FP Lab Test II, from LABORTECH s.r.o Opava, Czech Republic), located at the Technical University of Liberec Laboratory, with the applied load under displacement control at a loading rate of $2 \mathrm{~mm} / \mathrm{min}$, was used. The four-point flexural strength can be calculated as per the Equation (1):

$$
\sigma=\mathrm{Fl} /\left(\mathrm{bh}^{2}\right),
$$

where $\sigma$ is the four-point flexural strength in $\mathrm{MPa} ; \mathrm{F}$ is the load at a given point on the load-displacement curve in N; b is the width of the tested sample in $\mathrm{mm}$; $\mathrm{h}$ is the thickness of the sample in $\mathrm{mm}$; and $l$ is the support span in $\mathrm{mm}$.
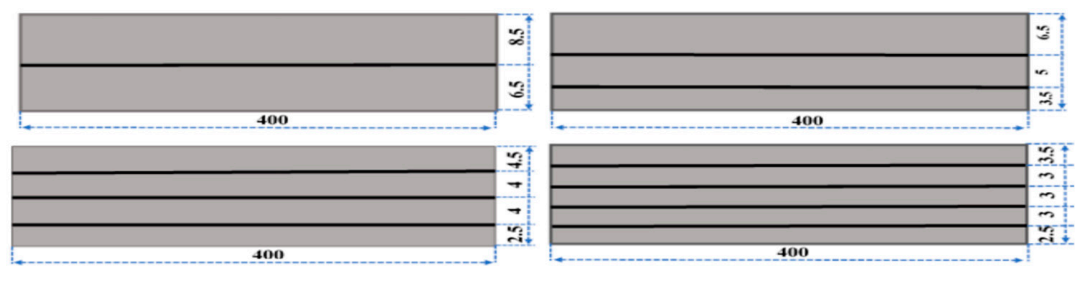

Figure 2. Schematic drawing of the arrangement of the basalt textile in the specimens (unit: $\mathrm{mm}$ ). 


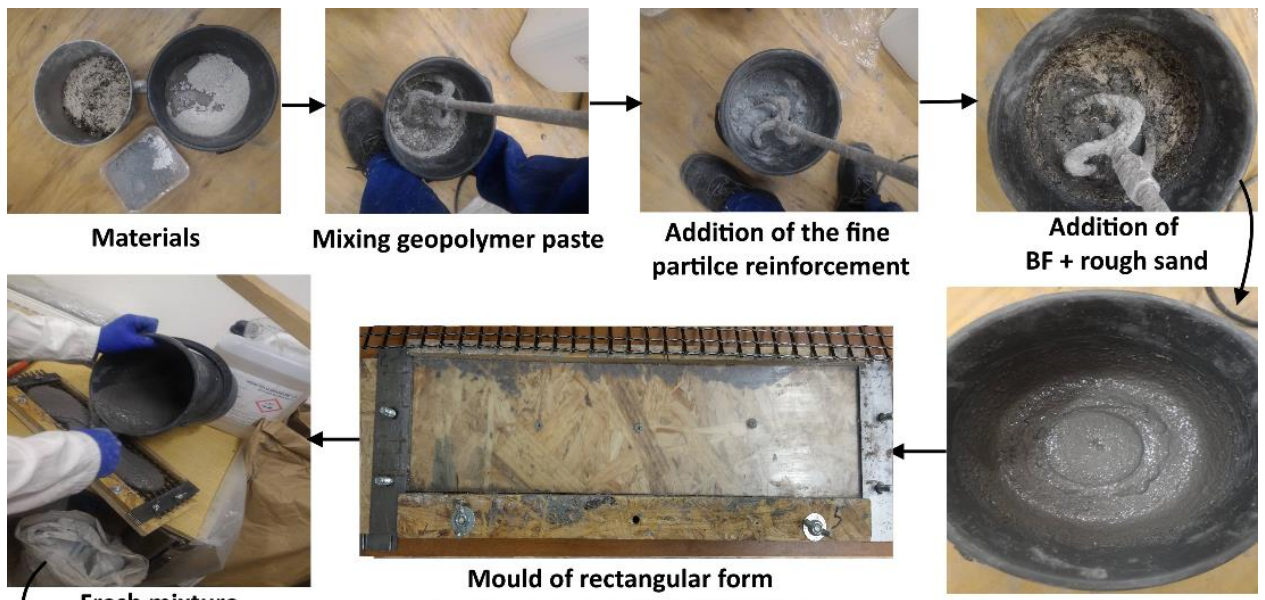

Fresh mixture

th dimension of $400 \times 100 \times 15 \mathrm{~mm}$

Homogeneous fresh mixture

cast into the mould
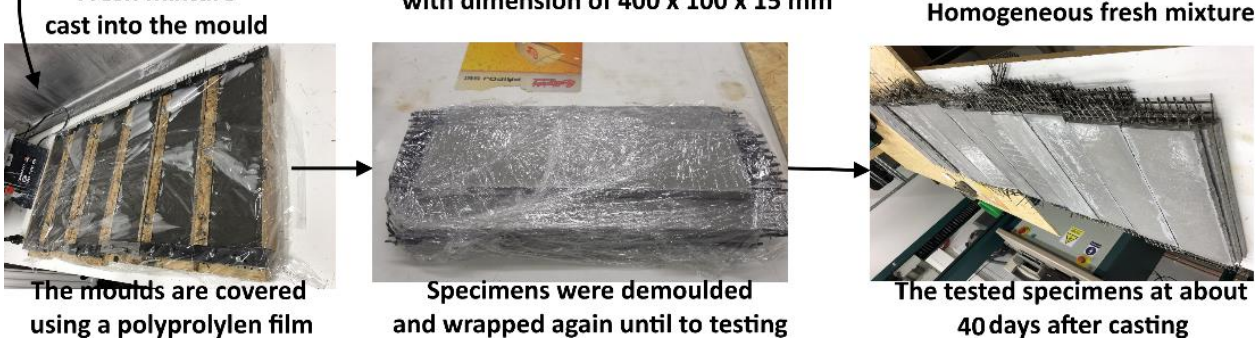

Figure 3. The manufacturing process of basalt textile reinforced specimens.
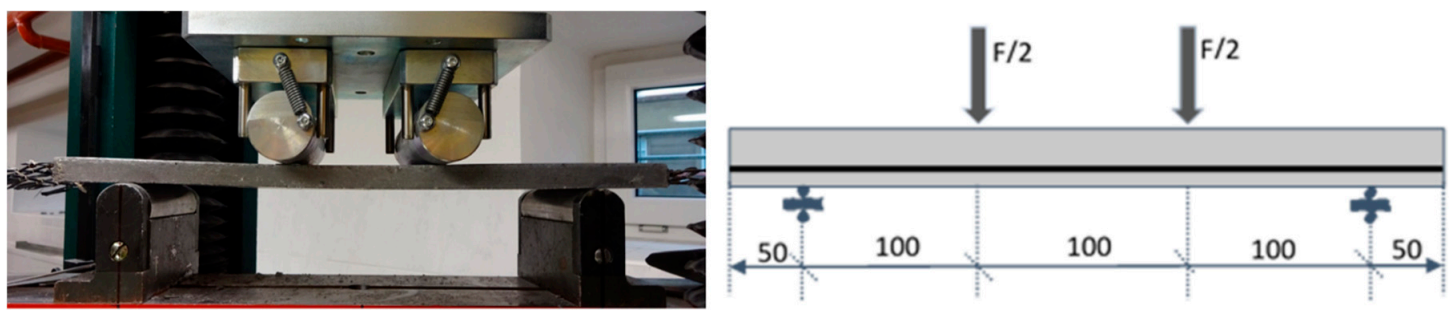

Figure 4. Four-point bending test for the BRG specimens.

\section{Results and Discussion}

\subsection{Development of the Mechanical Strength of the Geopolymer Mortar Matrix}

Figure 5 provides the information about the development of the mechanical strength of geopolymer mortar at the various periods of aging time. Three samples with dimension $30 \times 30 \times 150 \mathrm{~mm}^{3}$ for each ageing time were used for flexural test, and then the compressive strength was measured on both residual pieces obtained from flexural strength according to EN 196-1 standard [49]. It should be noted that the 28 day specimens were named as a reference sample. A number of these specimens were then kept at lab room $\left(\sim 26^{\circ} \mathrm{C}\right.$, with $65 \%$ relative humidity) in order to observe the development of the mechanical strength at the further ages, such as 60 days, 90 days, 150 days, and 180 days. From the Figure 5, it can be seen that geopolymer mortar containing different fillers with reasonable proportion can achieve relatively high mechanical strength. It should be said that the composition of mortar matrix described in Table 2 has been optimized in the laboratory. At the age of 7 days, the average mechanical strength of the samples is $11.5 \mathrm{MPa}$ in flexural and $78.8 \mathrm{MPa}$ in compressive strength. The average mechanical strength of the 28 day samples (reference sample) increases flexural strength by $22 \%$ and compressive strength by $35 \%$, compared to 7 days. 


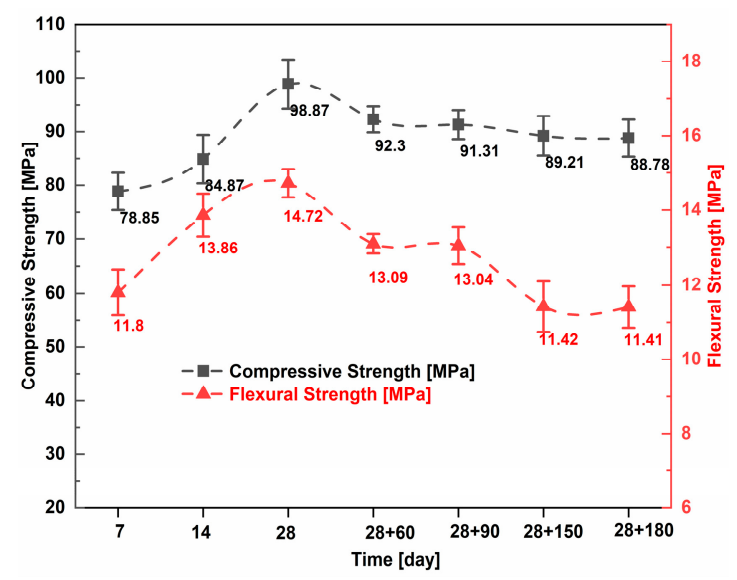

Figure 5. Development of the mechanical strength of geopolymer mortar.

Also from Figure 5, after 28 days of curing age it can be observed that both mechanical strengths show a downward trend with increasing aging time. While the samples show a slight decrease in compressive strength, the increasing aging time affects samples to have a more pronounced decrease in their flexural strength. This phenomenon is believed to be due to degradation of basalt fiber in alkaline environment $[27,40,41]$. When degradation of basalt fiber occurs, bond strength at the matrix/fiber interface will decrease; as a result, it can lead to poor bending resistance of the sample due to reduction of bridge effect of the chopped fiber in matrix. When compared to reference samples, the average mechanical strength of the samples with the increasing aging time of 60 days, 90 days, 150 days, 180 days decreases the compressive strength by $6.65 \%, 7.65 \%, 9.77 \%, 10.21 \%$, respectively, whereas decreases the flexural strength by $11.07 \%, 11.41 \%, 22.42 \%, 22.48 \%$, respectively. The influence of the chopped basalt fiber on the microstructure of geopolymer mortar is clearly shown in Figure 6. The chopped basalt fibers were randomly distributed in matrix and bridge over the micro-cracks resulting in enhancement of mechanical strength.

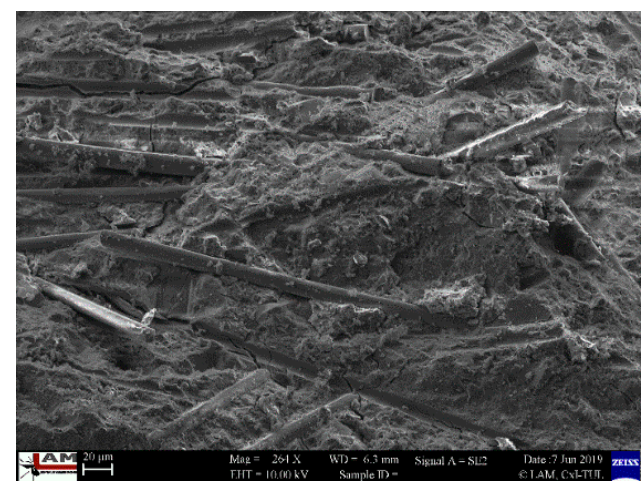

Figure 6. SEM microstructure of geopolymer mortar at the age of 28 days after casting.

\subsection{Flexural Response of Basalt Mesh Reinforced Geopolymer Composite}

The BRG specimens made of geopolymer mortar reinforced with one to four layers of each type of basalt mesh were tested at the age of about 40 days after casting by the four-point bending test method. Figure 7 represents the classical curves of flexural load-displacement behavior of textile reinforced concrete composite under the four-point flexural test, whereas the response of the flexural load-displacement curves of all the tested BRG specimens was described in Figure 8. As demonstrated in Figure 7, there are two distinctly different types of the load-displacement response of the specimens under flexure which consist of displacement-softening behavior and displacement-hardening behavior. In the field of fiber reinforced concrete, the materials refer to displacement-softening behavior (Figure 7a); 
when first crack initiates, the specimen is then destroyed due to localization of this crack. As further load continues to increase, the presence of the fiber is unable to produce the post-crack strength higher than the first-crack strength, however, it helps to restrict sudden brittle failure. Depending on the number of fiber yarns, fiber characteristics, and fiber alignment, the figure of the load, displacement curves softens down differently. In this case, BRG $10 \times 14-1$ L, BRG $22 \times 22-1$ L, BRG $22 \times 22-2 \mathrm{~L}$ and BRG $36 \times 36-1-4$ L produced a displacement-softening behavior with low load bearing capacity, see in Figure 8 . The remaining reinforced specimens, in contrast, show a displacement-hardening behavior, see in Figure $7 \mathrm{~b}$. This kind of behavior is accompanied by multiple cracks and further load bearing capacity after the formation of the first crack. In this behavior, the first crack stress is maintained, and the load is transferred to the other weak parts of the matrix through the fiber yarns. So the first crack does not localize to the increasing applied load. Instead, new cracks will be developed somewhere else in the matrix. Consequently, the increase in applied load results in formation of multi-cracks and higher load bearing capacity. For these specimens, load displacement curves were illustrated in three obvious parts corresponding to the stages in the bending test. The first stage is the elastic-linear pre-cracking stage which is established by the combination of geopolymer matrix and reinforcement through a linear increase in load until the first crack appears. The second stage is a multiple-cracking phase, as proven fluctuation of the curve when the load continues to apply. The number of cracks in each specimen almost results in this stage and the profile of this phase strongly relates to the number of textile layers, the stiffness of matrix, the organization of textile in matrix, and the bond strength at the interface between fiber yarn and matrix. The third stage is the post-cracking or crack-widening phase. It is indicated by the expansion of the cracks; the present cracks continue to become broader until the specimens break down by rupturing or slipping of the fiber yarns of the textile.

The effect of different layers of basalt textile having a small net size on the flexural performance of BRG specimens is described over the flexural load-displacement curves in Figure 8a. With the increasing number of textile layers in the composite, its bearing load capacity obviously increases. The figure of the curves changed positively when a textile layer increased from one layer to four layers. While specimens reinforced with one textile layer broke down smoothly due to localization of first crack, the increasing number of textile layers affect specimens having the failure manner into a more brittle fracture, i.e., a sudden loss of bearing load capacity after reaching the maximum load. Moreover, the dropping length of the second stage is also precisely related to the reinforcement rate, and the figure of this stage of the curve is significantly different. The higher the number of textile layers, the less fluctuation of the curve. This leads to a higher slope and flexural stiffness of specimens in this second stage. A similar conclusion is also represented for specimens reinforced with basalt textile having a middle net size, as see in Figure $8 \mathrm{~b}$. On the other hand, the specimens are required to be reinforced with a minimum of three layers in order to achieve a clear displacement-hardening behavior. Figure 8c exhibits the flexural load-displacement curves of specimens which are reinforced with basalt textile of a big net size. Unexpectedly, even when using of four layers; the specimens could not produce a displacement-hardening behavior. At this point, we can be concluded that the number of fiber yarns per each textile layer plays a key role in composite behavior of the specimens. For instance, with the same total number of fiber yarns in specimen, BRG $22 \times 22-3 \mathrm{~L}$ specimens showed a displacement-hardening behavior, whereas BRG $36 \times 36-4 \mathrm{~L}$ specimens was unable to do so. Figure $8 \mathrm{~d}$ gives a clear view of the effect of the net size on the response of flexural load-displacement curves of the BRG specimens, in which specimens reinforced with one textile layer are taken as a representation. Although these specimens show a displacement-softening behavior, specimens reinforced with basalt textile of smaller net size restrict the longer failure as well after the end of the first stage. 


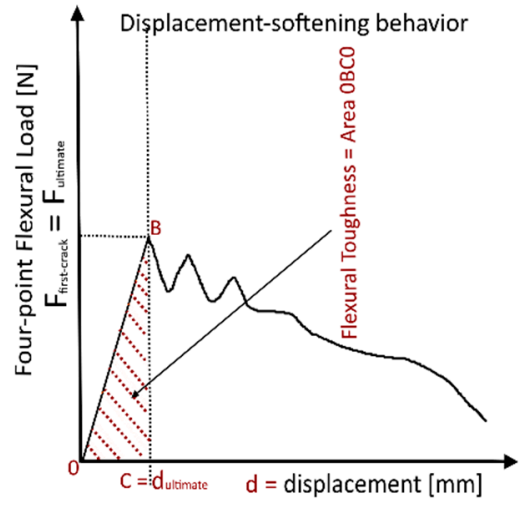

(a)

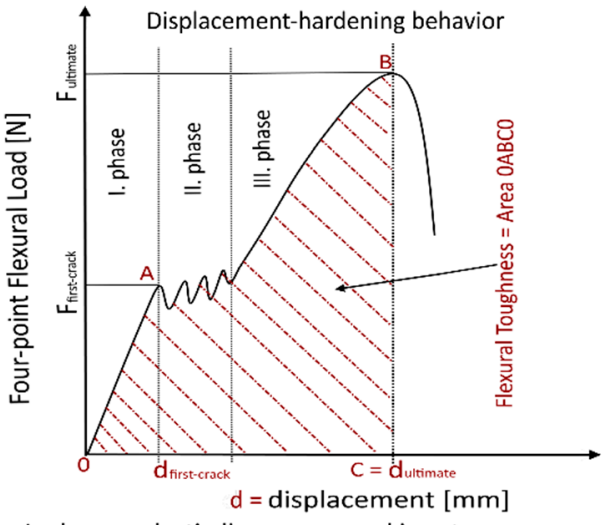

I. phase $=$ elastic-linear pre-cracking stage

II. phase $=$ muliple-cracking stage

III. phase $=$ post-cracking or crack-widening stage

(b)

Figure 7. Flexural load-displacement behavior of textile reinforced concrete composite under four-point flexural test: (a) displacement-softening behavior; (b) displacement-hardening behavior.

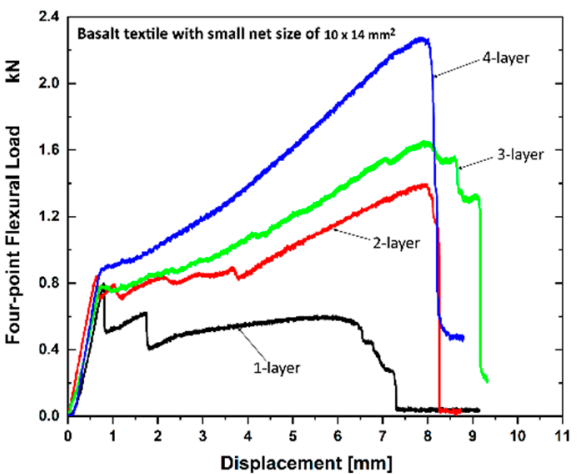

(a)

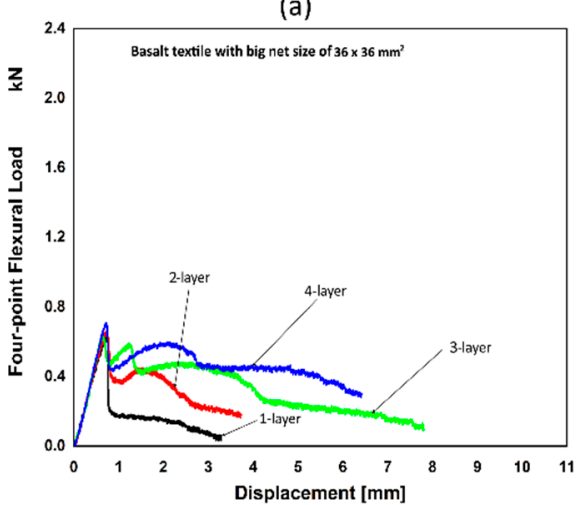

(c)

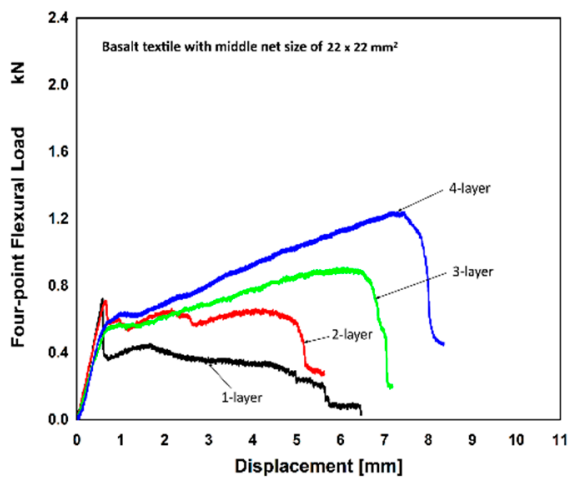

(b)

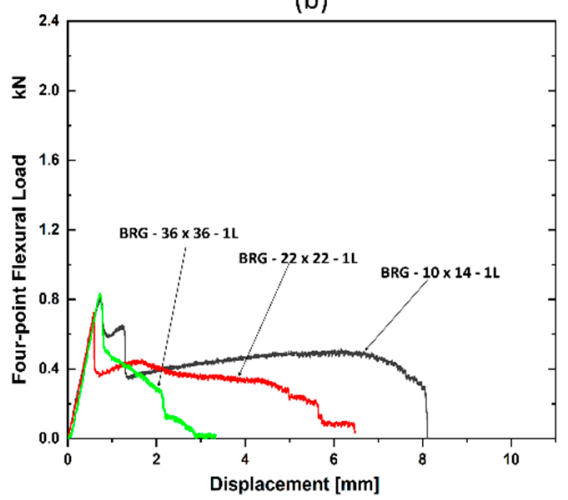

(d)

Figure 8. Flexural load-displacement curves of the specimens reinforced with the basalt textile having: (a) a net size of $10 \times 14 \mathrm{~mm}^{2}$; (b) a net size of $22 \times 22 \mathrm{~mm}^{2}$; (c) a net size of $36 \times 36 \mathrm{~mm}^{2}$; (d) comparison between one-layer reinforced specimens based on three.

Figure 9 shows the influence of ageing time on the durability of the BRG $10 \times 14-4$ L through the response of the average flexural load-displacement curves. It was found that with the increasing rate of aging time, the reinforced specimens decreased bearing-load capacity. This reduction can be attributed to degradation of the basalt fiber which is contained in both chopped basalt fiber and basalt mesh. 


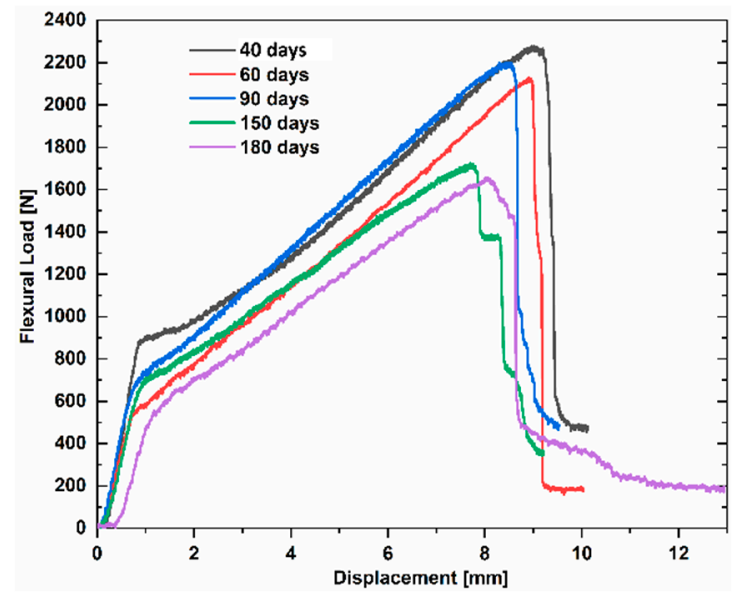

Figure 9. Flexural load-displacement curves of the specimens reinforced with four-layer basalt textile at the different periods of time.

\subsection{Mechanical Properties of Basalt Mesh Reinforced Geopolymer Composite}

Table 3 details the results of the mechanical properties of the tested BRG specimens obtained from the four-point bending test, such as first-crack load, first-crack stress, ultimate-crack load, ultimate-crack stress, ultimate displacement, the number of cracks, and flexural toughness, whereas Figure 10 shows representative graphs of the flexural strength and flexural toughness of the BRG specimens. It should be noted that, at this kind of composite material, mechanical properties extremely depend on both the arrangement of textile layer in matrix and direction of the applied load. For instance, the specimens reinforced with one layer do not always gain a stable value of flexural strength assuming that this textile layer is changed position of the arrangement, and it would bring higher bearing load capacity in case that textile layer is positioned closer to the tension edge with respect to ensuring the anchoring capability of textile [30]. Subsequently, the first-crack stress depends in part on the process of the specimen production. Due to insertion of textile mesh layer in specimens, the fresh mixture should be carefully cast into the mold in order to gain a good penetration of matrix between textile layers. As shown in Figure 10a, the green dashed line shows the significant variation of first-crack stress between the tested specimens. The BRG $22 \times 22-3 \mathrm{~L}, \mathrm{BRG} 22 \times 22-4 \mathrm{~L}$ specimens show the worst values in strength, for this reason it can be explained by fact that those specimens were badly produced which resulted in formation of many cavities surrounding the fiber yarn over the remaining specimens [50].The specimens reinforced with more number of textile layers, on the other hand, obviously lead to higher ultimate-crack stress, expect for those reinforced with basalt textile of a big net size. For basalt textile of a small net size, the specimens reinforced with two, three and four layers increased in ultimate-crack stress by $61.40 \% \mathrm{MPa}, 110.75 \% \mathrm{MPa}, 172.99 \% \mathrm{MPa}$, respectively, compared to one-layer reinforced specimens. For basalt textile of a middle net size, the specimens reinforced with three to four layers increased in ultimate-crack stress by $23.11 \% \mathrm{MPa}, 72.09 \% \mathrm{MPa}$, compared to one-layer reinforced specimens. For the basalt textile of a big net size, although four textile layers were applied, the specimens were still unable to obtain the ultimate-crack stress over first-crack stress. This can be explained by three reasons: (i) due to bigger net size making insufficient distribution of fiber yarns in the specimens, (ii) low tensile strength of itself fiber yarn affecting the composite behavior (see in Table 1), (iii) insertion of basalt textile in geopolymer mortar during ageing has caused a partial reduction in its mechanical strength due to alkaline environment [27,42]. Toughness, so-called energy absorption capacity, is defined as the resistance of a material to failure or crack propagation. Material with large energy absorption capacity obviously has higher energy to maintain crack propagation. Flexural toughness of the tested specimens is measured as area under respective load-displacement curves up to the peak load. According to the graphical representation of the toughness values in Figure 10b, it was found that using basalt mesh of big net size results in very poor resistance of the 
BRG specimens to failure and their toughness value is almost the same. A similar conclusion is also represented for the BRG $10 \times 14-1$ L, BRG $22 \times 22-2$ L and BRG 22×22-2 L. By contrast, toughness value of the remaining BRG specimens improved obviously with the increasing number of textile layers and type of net size. For example, the BRG 10x14-2L has a toughness value in $7177.50 \mathrm{~N} \cdot \mathrm{mm}$, this value increased to $11.55 \%$ (8365.33 N.mm) with BRG $10 \times 14-3 \mathrm{~L}$ and increased to $63.61 \%(11742.88$ $\mathrm{N} \cdot \mathrm{mm}$ ) with BRG $10 \times 14-4 \mathrm{~L}$. On the other hand, BRG $10 \times 14-4 \mathrm{~L}$ has toughness value in 11742.88 $\mathrm{N} \cdot \mathrm{mm}$, this value decreased to $44.67 \%(6496.57 \mathrm{~N} \cdot \mathrm{mm})$ with BRG $22 \times 22-4 \mathrm{~L}$ and decreased to $97.71 \%$ (268.56 N.mm) with BRG $36 \times 36-4 \mathrm{~L}$.

Table 3. Summary of the experimental results of BRG specimens.

\begin{tabular}{|c|c|c|c|c|c|c|c|}
\hline \multirow[b]{2}{*}{ Specimen } & \multicolumn{7}{|c|}{ The Average Value (Standard Deviation) } \\
\hline & $\begin{array}{c}\text { First-Crack } \\
\text { Load (N) }\end{array}$ & $\begin{array}{l}\text { First-Crack } \\
\text { Stress } \\
\text { (MPa) }\end{array}$ & $\begin{array}{l}\text { Ultimate } \\
\text { Load (N) }\end{array}$ & $\begin{array}{l}\text { Ultimate } \\
\text { Stress } \\
\text { (MPa) }\end{array}$ & $\begin{array}{c}\text { Ultimate } \\
\text { Displacement } \\
(\mathrm{mm})\end{array}$ & $\begin{array}{c}\text { Number } \\
\text { of Cracks } \\
{[-]} \\
\end{array}$ & $\begin{array}{c}\text { Flexural } \\
\text { Toughness } \\
(\mathrm{N} \cdot \mathrm{mm})\end{array}$ \\
\hline \multicolumn{8}{|c|}{ The experimental results of the specimens reinforced with the different types of the basalt textile } \\
\hline BRG $10 \times 14-1 \mathrm{~L}$ & $\begin{array}{l}802.87 \\
(5.44)\end{array}$ & $\begin{array}{l}10.70 \\
(0.07)\end{array}$ & $\begin{array}{l}802.87 \\
(5.44)\end{array}$ & $\begin{array}{l}10.70 \\
(0.07)\end{array}$ & $\begin{array}{c}0.74 \\
(0.04)\end{array}$ & $\begin{array}{c}2 \\
(0)\end{array}$ & $\begin{array}{l}279.74 \\
(23.50)\end{array}$ \\
\hline BRG $10 \times 14-2 \mathrm{~L}$ & $\begin{array}{c}838.11 \\
(5.15)\end{array}$ & $\begin{array}{l}11.17 \\
(0.07)\end{array}$ & $\begin{array}{c}1295.34 \\
(90.34)\end{array}$ & $\begin{array}{l}17.27 \\
(1.20)\end{array}$ & $\begin{array}{c}8.02 \\
(0.07)\end{array}$ & $\begin{array}{c}4 \\
(0)\end{array}$ & $\begin{array}{l}7177.50 \\
(394.91)\end{array}$ \\
\hline BRG $10 \times 14-3 \mathrm{~L}$ & $\begin{array}{l}792.11 \\
(67.55)\end{array}$ & $\begin{array}{l}10.56 \\
(0.90)\end{array}$ & $\begin{array}{l}1691.06 \\
(53.69)\end{array}$ & $\begin{array}{l}22.55 \\
(0.72)\end{array}$ & $\begin{array}{c}8.15 \\
(0.14)\end{array}$ & $\begin{array}{l}10.33 \\
(0.57)\end{array}$ & $\begin{array}{l}8365.33 \\
(677.24)\end{array}$ \\
\hline BRG $10 \times 14-4 \mathrm{~L}$ & $\begin{array}{l}819.70 \\
(99.01)\end{array}$ & $\begin{array}{l}10.93 \\
(1.32)\end{array}$ & $\begin{array}{c}2190.68 \\
(91.57)\end{array}$ & $\begin{array}{l}29.21 \\
(1.22)\end{array}$ & $\begin{array}{c}8.30 \\
(0.98)\end{array}$ & $\begin{array}{l}12 \\
(0)\end{array}$ & $\begin{array}{l}11742.88 \\
(131.25)\end{array}$ \\
\hline BRG $22 \times 22-1 \mathrm{~L}$ & $\begin{array}{l}736.37 \\
(11.46)\end{array}$ & $\begin{array}{c}9.82 \\
(0.15)\end{array}$ & $\begin{array}{l}736.37 \\
(11.46)\end{array}$ & $\begin{array}{c}9.82 \\
(0.15)\end{array}$ & $\begin{array}{c}0.68 \\
(0.15)\end{array}$ & $\begin{array}{c}2 \\
(0)\end{array}$ & $\begin{array}{l}234.16 \\
(35.25)\end{array}$ \\
\hline BRG $22 \times 22-2 \mathrm{~L}$ & $\begin{array}{l}646.61 \\
(69.91)\end{array}$ & $\begin{array}{c}8.62 \\
(0.93)\end{array}$ & $\begin{array}{l}695.98 \\
(41.75)\end{array}$ & $\begin{array}{c}9.28 \\
(0.56)\end{array}$ & $\begin{array}{c}1.06 \\
(0.41)\end{array}$ & $\begin{array}{c}2 \\
(0)\end{array}$ & $\begin{array}{c}400.87 \\
(136.56)\end{array}$ \\
\hline BRG $22 \times 22-3 \mathrm{~L}$ & $\begin{array}{l}565.00 \\
(26.64)\end{array}$ & $\begin{array}{c}7.53 \\
(0.36)\end{array}$ & $\begin{array}{l}907.39 \\
(39.24)\end{array}$ & $\begin{array}{l}12.09 \\
(0.52)\end{array}$ & $\begin{array}{c}6.43 \\
(0.54)\end{array}$ & $\begin{array}{c}5.67 \\
(0.57)\end{array}$ & $\begin{array}{l}4305.43 \\
(406.93)\end{array}$ \\
\hline BRG $22 \times 22-4 \mathrm{~L}$ & $\begin{array}{l}589.85 \\
(39.67)\end{array}$ & $\begin{array}{c}7.86 \\
(0.53)\end{array}$ & $\begin{array}{l}1267.17 \\
(58.97)\end{array}$ & $\begin{array}{l}16.90 \\
(0.79)\end{array}$ & $\begin{array}{c}7.46 \\
(0.31)\end{array}$ & $\begin{array}{c}6.67 \\
(0.57)\end{array}$ & $\begin{array}{l}6496.57 \\
(482.88)\end{array}$ \\
\hline BRG $36 \times 36-1 \mathrm{~L}$ & $\begin{array}{c}748.24 \\
(107.84)\end{array}$ & $\begin{array}{c}9.98 \\
(1.44)\end{array}$ & $\begin{array}{c}748.24 \\
(107.84)\end{array}$ & $\begin{array}{c}9.98 \\
(1.44)\end{array}$ & $\begin{array}{c}0.84 \\
(0.17)\end{array}$ & $\begin{array}{c}2 \\
(0)\end{array}$ & $\begin{array}{l}270.66 \\
(24.84)\end{array}$ \\
\hline BRG $36 \times 36-2$ L & $\begin{array}{l}666.29 \\
(73.63)\end{array}$ & $\begin{array}{c}8.88 \\
(0.98)\end{array}$ & $\begin{array}{l}666.29 \\
(73.63)\end{array}$ & $\begin{array}{c}8.88 \\
(0.98)\end{array}$ & $\begin{array}{c}0.72 \\
(0.02)\end{array}$ & $\begin{array}{c}2 \\
(0)\end{array}$ & $\begin{array}{l}240.30 \\
(28.05)\end{array}$ \\
\hline BRG $36 \times 36-3 \mathrm{~L}$ & $\begin{array}{c}741.11 \\
(101.47) \\
\end{array}$ & $\begin{array}{c}9.88 \\
(1.35)\end{array}$ & $\begin{array}{c}741.11 \\
(101.47)\end{array}$ & $\begin{array}{c}9.88 \\
(1.35)\end{array}$ & $\begin{array}{c}0.70 \\
(0.06)\end{array}$ & $\begin{array}{c}2 \\
(0)\end{array}$ & $\begin{array}{l}286.64 \\
(76.50)\end{array}$ \\
\hline BRG $36 \times 36-4$ L & $\begin{array}{l}717.70 \\
(7.60)\end{array}$ & $\begin{array}{c}9.57 \\
(0.10)\end{array}$ & $\begin{array}{l}717.70 \\
(7.60)\end{array}$ & $\begin{array}{c}9.57 \\
(0.10)\end{array}$ & $\begin{array}{c}0.69 \\
(0.08)\end{array}$ & $\begin{array}{c}2 \\
(0)\end{array}$ & $\begin{array}{l}268.58 \\
(35.54)\end{array}$ \\
\hline \multicolumn{8}{|c|}{ The experimental results of four-layer reinforcing specimens at the different periods of aging time } \\
\hline 40 day sample & $\begin{array}{l}819.70 \\
(99.01)\end{array}$ & $\begin{array}{l}10.93 \\
(1.32)\end{array}$ & $\begin{array}{c}2190.68 \\
(91.57)\end{array}$ & $\begin{array}{l}29.21 \\
(1.22)\end{array}$ & $\begin{array}{c}8.30 \\
(0.98)\end{array}$ & $\begin{array}{l}11.33 \\
(0.57)\end{array}$ & $\begin{array}{c}11742.88 \\
(131.25)\end{array}$ \\
\hline 60 day sample & $\begin{array}{l}509.66 \\
(53.48)\end{array}$ & $\begin{array}{c}6.79 \\
(0.71)\end{array}$ & $\begin{array}{l}2006.76 \\
(122.23)\end{array}$ & $\begin{array}{l}26.76 \\
(1.63)\end{array}$ & $\begin{array}{c}8.54 \\
(0.88)\end{array}$ & $\begin{array}{l}12 \\
(0)\end{array}$ & $\begin{array}{c}10126.90 \\
(859.55)\end{array}$ \\
\hline 90 day sample & $\begin{array}{l}619.33 \\
(37.12)\end{array}$ & $\begin{array}{c}8.25 \\
(0.49)\end{array}$ & $\begin{array}{l}2060.92 \\
(121.13)\end{array}$ & $\begin{array}{l}27.47 \\
(1.62)\end{array}$ & $\begin{array}{c}8.67 \\
(0.53)\end{array}$ & $\begin{array}{l}11.33 \\
(0.57)\end{array}$ & $\begin{array}{l}9864.42 \\
(483.69)\end{array}$ \\
\hline 150 day sample & $\begin{array}{c}614.33 \\
(5.51)\end{array}$ & $\begin{array}{c}8.19 \\
(0.07)\end{array}$ & $\begin{array}{c}1714.90 \\
(42.50)\end{array}$ & $\begin{array}{l}22.87 \\
(1.47)\end{array}$ & $\begin{array}{c}6.62 \\
(0.38)\end{array}$ & $\begin{array}{l}11.33 \\
(0.57)\end{array}$ & $\begin{array}{l}7634.17 \\
(667.48)\end{array}$ \\
\hline 180 day sample & $\begin{array}{l}531.67 \\
(26.10)\end{array}$ & $\begin{array}{c}7.08 \\
(0.35)\end{array}$ & $\begin{array}{l}1682.97 \\
(36.12)\end{array}$ & $\begin{array}{l}22.49 \\
(0.43)\end{array}$ & $\begin{array}{c}6.64 \\
(0.50)\end{array}$ & $\begin{array}{l}11.33 \\
(0.57)\end{array}$ & $\begin{array}{l}6995.69 \\
(793.56)\end{array}$ \\
\hline
\end{tabular}




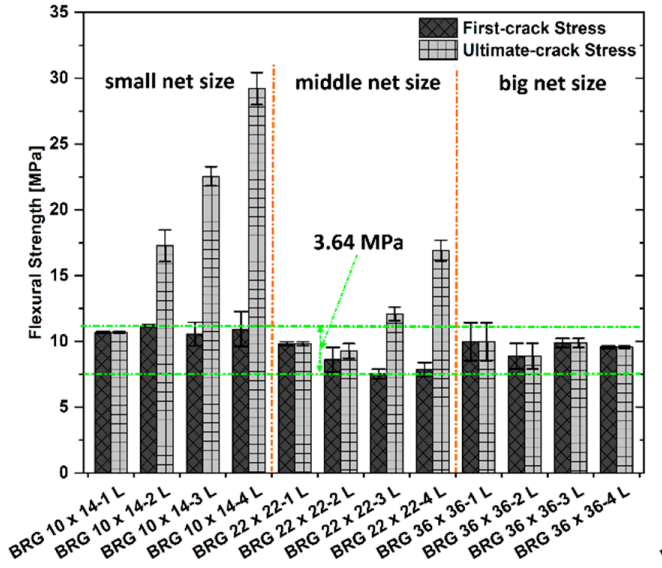

(a)

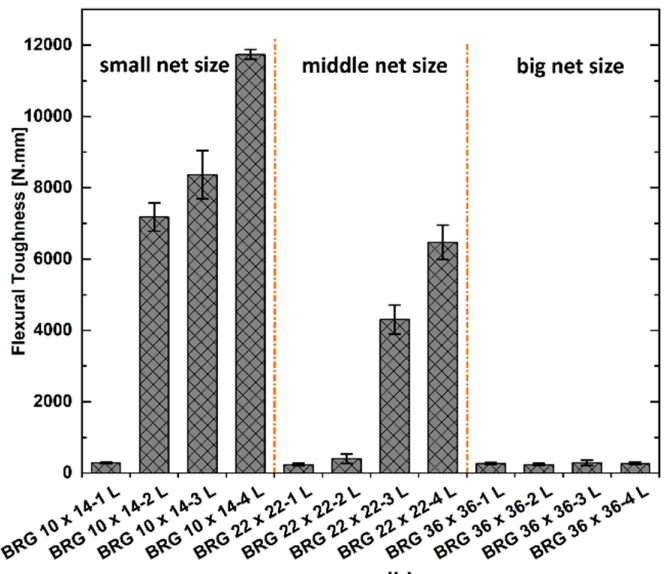

(b)

Figure 10. The comparison of the flexural strength (a) and flexural toughness (b) of the BRG specimens corresponding to various net size and number of textile layers.

Figure 11 provides information about the average values of the flexural strength and flexural toughness of the BRG $10 \times 14-4 \mathrm{~L}$ specimens at the different periods of aging time. In general, with the increasing ageing time, the mechanical strength of the BRG specimens decreased significantly especially after 180 days of ageing. BRG reference has flexural strength value in $29.21 \mathrm{MPa}, \mathrm{BRG}$ specimens aged at 60 days, 90 days, 150 days, 180 days decreased in flexural strength by $8.39 \%$ (26.76 MPa), $6.0 \%$ (27.47 MPa), 21.7\% (22.87 MPa), 23\% (22.49 MPa), respectively (see in Figure 11a and Table 3). A similar reduction of flexural toughness of the BRG specimens can be seen in Figure 11b.

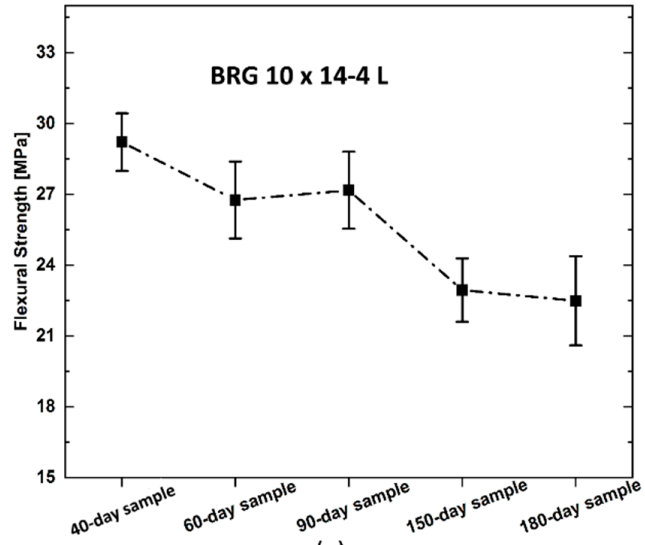

(a)

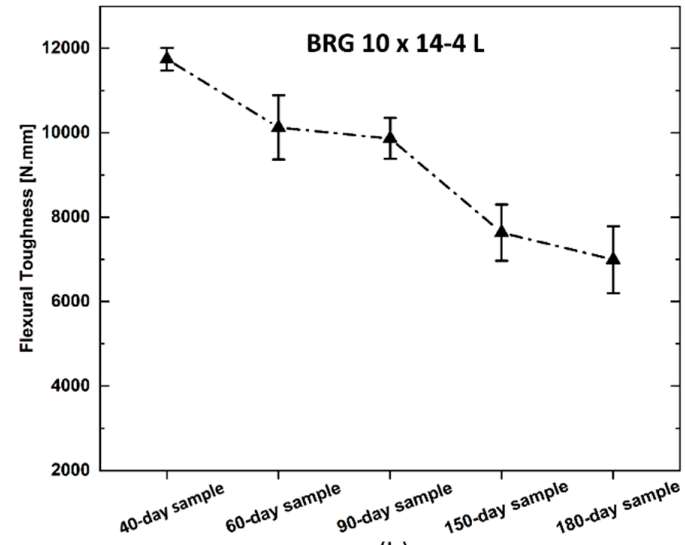

(b)

Figure 11. The comparison of flexural strength (a) and flexural toughness (b) of the BRG specimens over the different periods of aging time.

\subsection{Failure Mode}

Figure 12 shows the failure mode of the BRG specimens under the four-point bending test. In general, all of the specimens had the same failure mode by the flexural failure due to the rupture of basalt fiber yarn in matrix, and no debonding of the fiber yarn or a gradual peeling process of geopolymer mortar happened during the testing. The difference can be seen clearly in the number of cracks and crack spacing between the reinforced specimens. With the increasing number of reinforcing layers, the BRG specimens displayed more cracks and narrow crack spacing; for this reason, it is because the amount of energy that the specimens absorb will be greater and accumulates faster during the multiple cracking stage. Moreover, the number of cracks also depends significantly on the number of fiber yarns per each layer (Table 3). The failure with single crack results in the specimens BRG $10 \times 14-1$ L, BRG $22 \times 22-1$ L, BRG $22 \times 22-2$ L, and all specimens BRG $36 \times 36-1-4$ L. It can be said that 
using basalt textile of a big net size (shown in Figure 12c), even when using four strengthening layers also make it impossible to help BRG specimens achieving a displacement-hardening behavior. The failure of these specimens is characterized by the widening of the first crack.

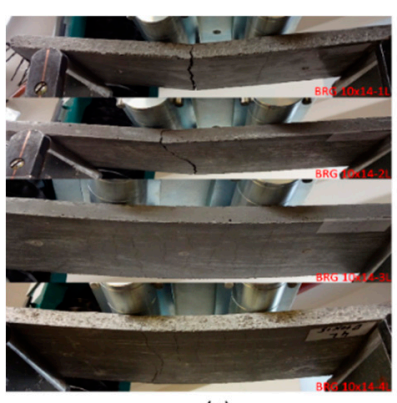

(a)

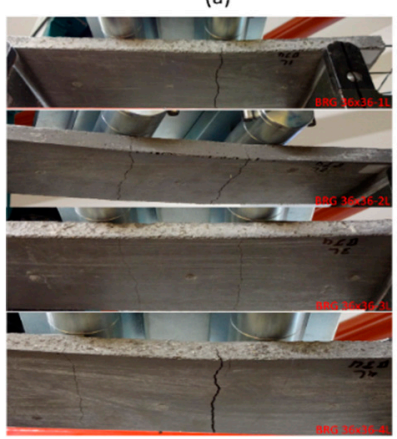

(c)

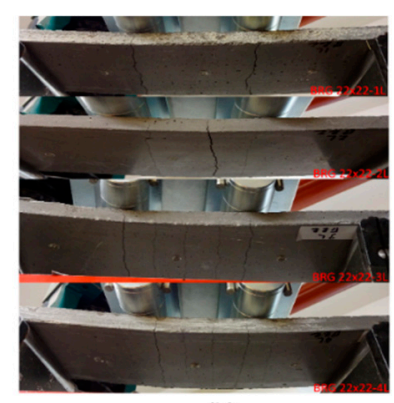

(b)

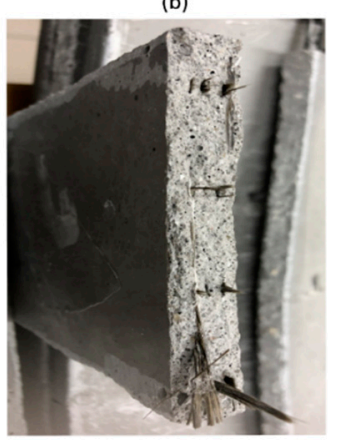

(d)

Figure 12. Photographs of cracks distribution of the tested specimens: (a) basalt textile of a net size of $10 \times 14 \mathrm{~mm}^{2}$; (b) basalt textile of a net size of $22 \times 22 \mathrm{~mm}^{2}$; (c) basalt textile of a net size of $36 \times 36 \mathrm{~mm}^{2}$; (d) rupture failure of the tested specimen.

The imprint of fiber yarn embedded in mortar matrix was clearly shown in Figure 13. It can be observed that good specimen production leads to better penetration of fresh mortar between textile layers resulting in a denser matrix structure with less cavities at the mortar matrix-fiber yarn interface (Figure 13a). Additionally, the presence of filaments separated from fiber yarn indicates that there is a good bonding strength at interface between fiber yarn and mortar matrix. By contrast, the image shown in Figure 13b points out a different view of the mortar matrix-fiber interface, which shows many cavities.

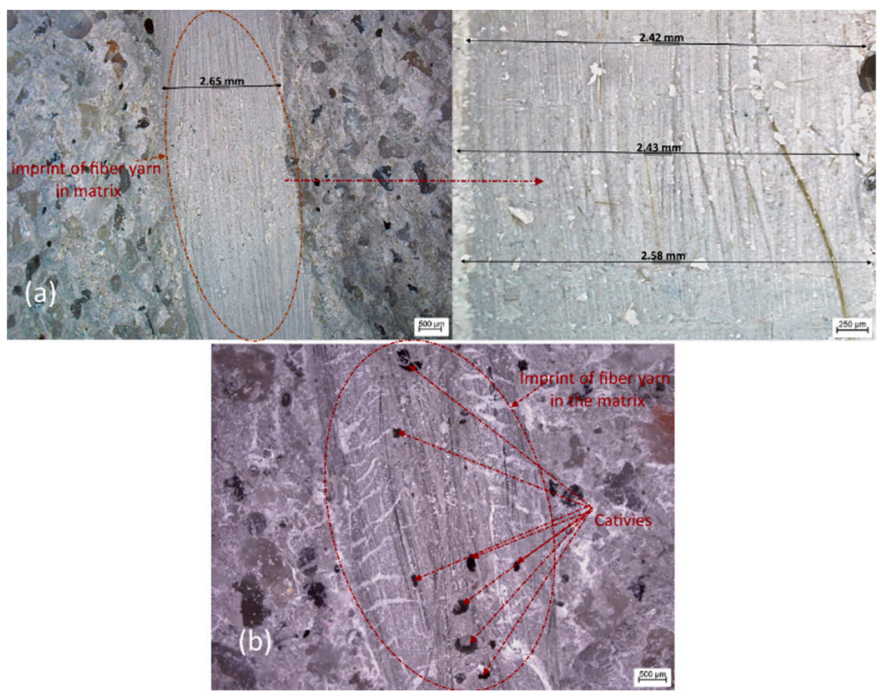

Figure 13. Geopolymer matrix/fiber yarn interface: (a) BRG $10 \times 14-4 \mathrm{~L}$; (b) BRG $22 \times 22-3 \mathrm{~L}$. 


\section{Conclusions}

Based on three types of the basalt mesh corresponding to net size provided by Frisiverto S.R.O company Czech Republic, this paper investigated the flexural performance of basalt textile-reinforced geopolymer mortar composite. The specimens were produced and tested at the age of about 40 days after casting in order to evaluate the influence of the number of textile layers and net size on the flexural strength of the reinforced specimens. Additionally, a number of the BRG 10 $\times 14-4 \mathrm{~L}$ specimens were left for longer ageing times in order to determine their degradation over time. Based on the experimental results achieved, the following conclusions were outlined:

- With the arrangement of basalt mesh in the BRG specimens in this study, displacement-hardening behavior can only be achieved when the specimens are reinforced with multiple textile layers. With the increasing number of textile layers, the mechanical properties of the BRG specimens were improved significantly, especially with the BRG specimens reinforced with basalt mesh having a small net size. There is no impact on the mechanical strength of the BRG reinforced with basalt mesh of big net size, failure of these BRG specimens is due to localization of the first-crack. This can be attributed to two main reasons: (i) partial loss of the mechanical strength of basalt fiber in an alkali environment, (ii) low tensile strength of the fiber yarn while using basalt mesh of big net size reflects the behavior of the BRG specimens. It can be concluded that using basalt mesh of big net size as reinforcement is not useful. So, the author suggests that only basalt textile of small net size should be used to reinforced in specimens due to reinforcement effectiveness; or in case of using basalt mesh of big net size, fiber yarn should be resized to its size by way of fiber yarn that should be made of more individual filaments to improve its low tensile strength.

- Under four-point bending tests, all BRG specimens have the same failure mode by flexural failure due to the rupture of fiber yarn in mortar matrix and no debonding of fiber yarn or a gradual peeling process of mortar matrix during testing. On the other hand, the specimens reinforced with more textile layers lead to a greater number of cracks.

- When the BRG specimens were exposed at longer ageing times (60, 90, 150, 180 days), degradation of the mechanical strength with the increasing ageing time was revealed. The obvious loss of the durability is after 150 days of ageing time compared to the reference. This reduction happened in both specimens of mortar matrix and BRG specimens, so it can be attributed to the presence of basalt fiber in the geopolymer. The author suggests that the BRG specimens should continue to be tested at longer aging times in order to evaluate their durability.

- The specimen production phase also plays an important role in the first-crack strength of these composites. The subjectivity in the specimen production can lead to the BRG specimens having many cavities at the interface between mortar matrix and fiber yarn which results in a decrease of the mechanical strength of the BRG specimens.

Author Contributions: H.L.C. designed, performed the experiment and wrote the paper, S.L.V. prepared and tested the specimens, V.K. performed the experiment and supported to test the specimens, L.V. performed the experiment and analyzed the graphics, T.B. and P.L. reviewed and supervisor the paper.

Funding: This work was supported by Institutional Endowment for the Long Term Conceptual Development of Research Institutes, as provided by the Ministry of Education, Youth and Sports of the Czech Republic in the year 2018 and by the project "Application of geopolymer composites as fire, AGK", registration number VI20172019055, were obtained through the financial support of the Ministry of interior in the program "The Safety Research of the Czech Republic" 2015-2020 (BV III/1-VS).

Acknowledgments: First author is acknowledged to the Technical University of Liberec, Faculty of Mechanical Engineering and Ministry of Education, Youth and Sports, Czech Republic for providing the fund and facilities to write this paper.

Conflicts of Interest: The authors declare no conflict of interest. 


\section{References}

1. Dey, V.; Zani, G.; Colombo, M.; Di Prisco, M.; Mobasher, B. Flexural impact response of textile-reinforced aerated concrete sandwich panels. Mater. Des. 2015, 86, 187-197. [CrossRef]

2. Mechtcherine, V. Novel cement-based composites for the strengthening and repair of concrete structures. Constr. Build. Mater. 2013, 41,365-373. [CrossRef]

3. Portal, N.W.; Flansbjer, M.; Zandi, K.; Wlasak, L.; Malaga, K. Bending behaviour of novel Textile Reinforced Concrete-foamed concrete (TRC-FC) sandwich elements. Compos. Struct. 2017, 177, 104-118. [CrossRef]

4. Colombo, I.G.; Colombo, M.; Di Prisco, M. Bending behaviour of Textile Reinforced Concrete sandwich beams. Constr. Build. Mater. 2015, 95, 675-685. [CrossRef]

5. Davidovits, J. Geopolymers: Ceramic-like inorganic polymers. J. Ceram. Sci. Technol. 2017, 8, 335-350.

6. Davidovits, P.J. Properties of Geopolymer Cements. In Proceedings of the First international conference on alkaline cements and concretes, Kiev, Ukraine, 11-14 October 1994; pp. 131-149.

7. Barbosa, V.F.; MacKenzie, K.J.; Thaumaturgo, C. Synthesis and characterisation of materials based on inorganic polymers of alumina and silica: Sodium polysialate polymers. Int. J. Inorg. Mater. 2000, 2, 309-317. [CrossRef]

8. Duxson, P.; Provis, J.L.; Lukey, G.C.; Mallicoat, S.W.; Kriven, W.M.; Van Deventer, J.S. Understanding the relationship between geopolymer composition, microstructure and mechanical properties. Colloids Surf. A Physicochem. Eng. Asp. 2005, 269, 47-58. [CrossRef]

9. Lamuta, C.; Candamano, S.; Crea, F.; Pagnotta, L. Direct piezoelectric effect in geopolymeric mortars. Mater. Des. 2016, 107, 57-64. [CrossRef]

10. Meyer, C. The greening of the concrete industry. Cem. Concr. Compos. 2009, 31, 601-605. [CrossRef]

11. Verian, K.P.; Behnood, A. Effects of deicers on the performance of concrete pavements containing air-cooled blast furnace slag and supplementary cementitious materials. Cem. Concr. Compos. 2018, 90, 27-41. [CrossRef]

12. Teh, S.H.; Wiedmann, T.; Castel, A.; De Burgh, J. Hybrid life cycle assessment of greenhouse gas emissions from cement, concrete and geopolymer concrete in Australia. J. Clean. Prod. 2017, 152, 312-320. [CrossRef]

13. Davidovits, J. How to cite this paper: False Values on $\mathrm{CO}_{2}$ Emission for Geopolymer Cement/Concrete published in Scientific Papers The Manufacture of Geopolymer Cement/Concrete. Geopolym. Inst. Libr. 2015, 24, 1-9.

14. Abdalqader, A.F.; Jin, F.; Al-Tabbaa, A. Development of greener alkali-activated cement: Utilisation of sodium carbonate for activating slag and fly ash mixtures. J. Clean. Prod. 2016, 113, 66-75. [CrossRef]

15. Candamano, S.; De Luca, P.; Frontera, P.; Crea, F. Production of Geopolymeric Mortars Containing Forest Biomass Ash as Partial Replacement of Metakaolin. Environments 2017, 4, 74. [CrossRef]

16. Novitskii, A.G. High-Temperature Heat-Insulating Materials Based on Fibers from Basalt-Type Rock Materials. Refract. Ind. Ceram. 2004, 45, 144-146. [CrossRef]

17. Fiore, V.; Scalici, T.; Di Bella, G.; Valenza, A. A review on basalt fibre and its composites. Compos. Part B Eng. 2015, 74, 74-94. [CrossRef]

18. Punurai, W.; Kroehong, W.; Saptamongkol, A.; Chindaprasirt, P. Mechanical properties, microstructure and drying shrinkage of hybrid fly ash-basalt fiber geopolymer paste. Constr. Build. Mater. 2018, 186, 62-70. [CrossRef]

19. Branston, J.; Das, S.; Kenno, S.Y.; Taylor, C. Influence of basalt fibres on free and restrained plastic shrinkage. Cem. Concr. Compos. 2016, 74, 182-190. [CrossRef]

20. Yoo, D.-Y.; Lee, J.-H.; Yoon, Y.-S. Effect of fiber content on mechanical and fracture properties of ultra high performance fiber reinforced cementitious composites. Compos. Struct. 2013, 106, 742-753. [CrossRef]

21. Arslan, M.E. Effects of basalt and glass chopped fibers addition on fracture energy and mechanical properties of ordinary concrete: CMOD measurement. Constr. Build. Mater. 2016, 114, 383-391. [CrossRef]

22. Branston, J.; Das, S.; Kenno, S.Y.; Taylor, C. Mechanical behaviour of basalt fibre reinforced concrete. Constr. Build. Mater. 2016, 124, 878-886. [CrossRef]

23. Jiang, C.; Fan, K.; Wu, F.; Chen, D. Experimental study on the mechanical properties and microstructure of chopped basalt fibre reinforced concrete. Mater. Des. 2014, 58, 187-193. [CrossRef] 
24. Kizilkanat, A.B.; Kabay, N.; Akyuncu, V.; Chowdhury, S.; Akça, A.H. Mechanical properties and fracture behavior of basalt and glass fiber reinforced concrete: An experimental study. Constr. Build. Mater. 2015, 100, 218-224. [CrossRef]

25. Zheng, Y.-Z.; Wang, W.-W.; Brigham, J.C. Flexural behaviour of reinforced concrete beams strengthened with a composite reinforcement layer: BFRP grid and ECC. Constr. Build. Mater. 2016, 115, 424-437. [CrossRef]

26. Du, Y.; Zhang, X.; Zhou, F.; Zhu, D.; Zhang, M.; Pan, W. Flexural behavior of basalt textile-reinforced concrete. Constr. Build. Mater. 2018, 183,7-21. [CrossRef]

27. Sim, J.; Park, C.; Moon, D.Y. Characteristics of basalt fiber as a strengthening material for concrete structures. Compos. Part B Eng. 2005, 36, 504-512. [CrossRef]

28. Marcari, G.; Basili, M.; Vestroni, F. Experimental investigation of tuff masonry panels reinforced with surface bonded basalt textile-reinforced mortar. Compos. Part B Eng. 2017, 108, 131-142. [CrossRef]

29. Di Ludovico, M.; Prota, A.; Manfredi, G. Structural Upgrade Using Basalt Fibers for Concrete Confinement. J. Compos. Constr. 2010, 14, 541-552. [CrossRef]

30. Le Chi, H.; Louda, P.; Periyasamy, A.P.; Bakalova, T.; Kovacic, V. Flexural Behavior of Carbon Textile-Reinforced Geopolymer Composite Thin Plate. Fibers 2018, 6, 87. [CrossRef]

31. Rill, E.; Lowry, D.R.; Kriven, W.M. Properties of Basalt Fiber Reinforced Geopolymer Composites. In Proceedings of the Strategic Materials and Computational Design-A Collection of Papers Presented at the 34th International Conference on Advanced Ceramics and Composites, Daytona Beach, FL, USA, 24-29 January 2010; pp. 57-67.

32. Shaikh, F.; Haque, S. Behaviour of Carbon and Basalt Fibres Reinforced Fly Ash Geopolymer at Elevated Temperatures. Int. J. Concr. Struct. Mater. 2018, 12, 35. [CrossRef]

33. Behera, P.; Baheti, V.; Militky, J.; Louda, P. Elevated temperature properties of basalt microfibril filled geopolymer composites. Constr. Build. Mater. 2018, 163, 850-860. [CrossRef]

34. Li, W.; Xu, J. Mechanical properties of basalt fiber reinforced geopolymeric concrete under impact loading. Mater. Sci. Eng. A 2009, 505, 178-186. [CrossRef]

35. Ribero, D.; Kriven, W.M. Properties of Geopolymer Composites Reinforced with Basalt Chopped Strand Mat or Woven Fabric. J. Am. Ceram. Soc. 2016, 99, 1192-1199. [CrossRef]

36. Hung, T.D.; Louda, P.; Kroisová, D.; Bortnovsky, O.; Xiem, N.T. New Generation of Geopolymer Composite for Fire-Resistance. In Advances in Composite Materials-Analysis of Natural and Man-Made Materials; IntechOpen: London, UK, 2012.

37. Samal, S.; Thanh, N.P.; Petríková, I.; Marvalová, B.; Vallons, K.A.; Lomov, S.V. Correlation of microstructure and mechanical properties of various fabric reinforced geo-polymer composites after exposure to elevated temperature. Ceram. Int. 2015, 41, 12115-12129. [CrossRef]

38. Samal, S.; Marvalová, B.; Petríková, I.; Vallons, K.A.; Lomov, S.V.; Rahier, H. Impact and post impact behavior of fabric reinforced geopolymer composite. Constr. Build. Mater. 2016, 127, 111-124. [CrossRef]

39. Welter, M.; Schmücker, M.; MacKenzie, K.J.D. Evolution of the fibre-matrix interactions in basalt-fibre-reinforced geopolymer-matrix composites after heating. J. Ceram. Sci. Technol. 2015, 6, 17-24.

40. Scheffler, C.; Forster, T.; Mader, E.; Heinrich, G.; Hempel, S.; Mechtcherine, V. Aging of alkali-resistant glass and basalt fibers in alkaline solutions: Evaluation of the failure stress by Weibull distribution function. J. Non-Crystalline Solids 2009, 355, 2588-2595. [CrossRef]

41. Wei, B.; Cao, H.; Song, S. Tensile behavior contrast of basalt and glass fibers after chemical treatment. Mater. Des. 2010, 31, 4244-4250. [CrossRef]

42. Portal, N.W.; Flansbjer, M.; Johannesson, P.; Malaga, K.; Lundgren, K. Tensile behaviour of textile reinforcement under accelerated ageing conditions. J. Build. Eng. 2016, 5, 57-66. [CrossRef]

43. Zhang, H.Y.; Lv, H.R.; Kodur, V.; Qi, S.L. Comparative fire behavior of geopolymer and epoxy resin bonded fiber sheet strengthened RC beams. Eng. Struct. 2018, 155, 222-234.

44. Ferone, C.; Colangelo, F.; Roviello, G.; Asprone, D.; Menna, C.; Balsamo, A.; Prota, A.; Cioffi, R.; Manfredi, G. Application-Oriented Chemical Optimization of a Metakaolin Based Geopolymer. Materials 2013, 6, 1920-1939. [CrossRef] [PubMed]

45. Katakalos, K.; Papakonstantinou, C.G. Fatigue of Reinforced Concrete Beams Strengthened with Steel-Reinforced Inorganic Polymers. J. Compos. Constr. 2009, 13, 103-112. [CrossRef] 
46. Menna, C.; Asprone, D.; Ferone, C.; Colangelo, F.; Balsamo, A.; Prota, A.; Cioffi, R.; Manfredi, G. Use of geopolymers for composite external reinforcement of RC members. Compos. Part B Eng. 2013, 45, 1667-1676. [CrossRef]

47. Tamburini, S.; Natali, M.; Garbin, E.; Panizza, M.; Favaro, M.; Valluzzi, M.R. Geopolymer matrix for fibre reinforced composites aimed at strengthening masonry structures. Constr. Build. Mater. 2017, 141, 542-552. [CrossRef]

48. Khalid, H.R.; Ha, S.; Park, S.M.; Kim, G.; Lee, H. Interfacial bond behavior of FRP fabrics bonded to fiber-reinforced geopolymer mortar. Compos. Struct. 2015, 134, 353-368. [CrossRef]

49. Irish Standard. Methods of testing cement. Part 1 Determ Strength; NSAI: Dublin, Ireland, 2005.

50. D'Antino, T.; Papanicolaou, C. Mechanical characterization of textile reinforced inorganic-matrix composites. Compos. Part B Eng. 2017, 127, 78-91. [CrossRef]

(C) 2019 by the authors. Licensee MDPI, Basel, Switzerland. This article is an open access article distributed under the terms and conditions of the Creative Commons Attribution (CC BY) license (http://creativecommons.org/licenses/by/4.0/). 